\title{
Growth of the Cichla temensis Humboldt, 1821 (Perciformes: Cichlidae) from the middle rio Negro, Amazonas, Brazil
}

\author{
Caroline Pereira Campos ${ }^{1}$, Carlos Edwar de Carvalho Freitas ${ }^{1}$ and Sidineia Amadio ${ }^{2}$
}

This study aimed to estimate age and growth of the peacock bass Cichla temensis from the rio Negro (Brazilian Amazonia) by analyzing scale annuli. Specimens were captured between October 2011 and September 2012 in the main channel of the river and in adjacent lakes in the municipality of Barcelos, AM, Brazil. Six growth checks were identified on the scales of specimens. The annual variation in body condition observed suggests that fat is accumulated during the dry season. Results for the GSI (gonadosomatic index) showed that peak reproduction occurred in the receding-water period, indicating that the fish had energy deficiencies as a result of reproductive activity. RMI (relative marginal increment) analysis revealed that an annulus is formed once a year during the receding-water period. The population parameters estimated were $\mathrm{L}_{50}$ (length at sexual maturity) $=31.11 \mathrm{~cm}, \mathrm{~L} \infty$ (asymptotic length) $=68.05 \mathrm{~cm}, \mathrm{k}$ (growth coefficient) $=0.20 . \mathrm{year}^{-1}$ and $\mathrm{A}_{0.95}$ (longevity) $=14$ years. Our results corroborate the validity of using growth rings in scales as indicators to estimate the age and growth rate of Cichla temensis in the middle rio Negro.

Este estudo teve como objetivo estimar a idade e o crescimento do tucunaré Cichla temensis do rio Negro (Amazônia brasileira) por meio de anéis nas escamas. Os espécimes foram capturados entre outubro de 2011 e setembro de 2012, no canal principal e lagos adjacentes, no município de Barcelos, AM, Brasil. Seis anéis de crescimento foram identificados nas escamas de $C$. temensis. A variação anual observada no fator de condição sugere que o acúmulo de gordura ocorreu durante o período de seca. Os resultados de IGS (índice gonadossomático) indicaram que o pico da reprodução ocorreu no período da vazante e que a espécie teve um déficit de energia em seu organismo, devido à atividade reprodutiva. Análise do IMR (incremento marginal relativo) mostrou que há formação de anel uma vez por ano, no período da vazante. Os parâmetros populacionais estimados para C. temensis foram: $\mathrm{L}_{50}$ (comprimento da maturidade sexual) $=31,11 \mathrm{~cm} ; \mathrm{L} \infty$ (comprimento assintótico) $=68,05 \mathrm{~cm} ; \mathrm{k}$ (coeficiente de crescimento) $=0,20 . \mathrm{ano}^{-1} \mathrm{e}_{0,95}$ (longevidade ) 14 anos. Nossos resultados confirmaram a validade do uso das marcas de crescimento, em escamas, para estudo de crescimento de Cichla temensis, como indicadoras da idade e do ritmo de crescimento dessa espécie na região do médio rio Negro.

Keywords: Age, Hydrological period, Peacock bass, Population parameters, Scales.

\section{Introduction}

Growth studies of a given fish stock require determining the correct age of the individuals (Weatherley \& Gill, 1987), which is essential to estimate the size of the stock, mortality rate and recruitment, among other parameters. Growth rate in turn is related to the availability of food, habitat and temperature, which are influenced by seasonal variations (Weatherley, 1972). Age can be estimated by analyzing the length distribution over time or by interpreting growth marks in rigid structures such as scales, otoliths, vertebrae and opercula (Fonteles Filho, 2011).
The formation of annuli is related to partial or complete reduction in somatic growth during one or more periods of the year (Casselman, 1983; Welcomme, 1992). In temperate regions the temperature decreases drastically during the winter, causing a reduction in growth and the consequent formation of these marks (Fonteles Filho, 2011). However, as the annual temperature variation in tropical regions is small, it was believed that it would not be possible to identify growth marks in calcified structures (Fonteles Filho, 2011) and, consequently, that this method could not be used to determine age in tropical fish species. For this reason, until recently, growth parameters in these

${ }^{1}$ Universidade Federal do Amazonas, UFAM, mini Campus, PIATAM, Av. General Rodrigo Octávio 3000, Coroado I, 69077000 Manaus, AM, Brazil. (CPC) krolpc@gmail.com (corresponding author), (CECF) cefreitas@ufam.edu.br ${ }^{2}$ Instituto Nacional de Pesquisa da Amazônia, INPA, Av. André Araújo 2936, Petrópolis, 69067-375 Manaus, AM, Brazil. sidamadioinpa@ gmail.com 
regions were generally estimated indirectly from lengthfrequency data (Petrere Jr., 1983; Isaac \& Ruffino, 1996; Ruffino \& Isaac, 1999; Santos Filho \& Batista, 2009; Bevilaqua \& Soares, 2010; Campos \& Freitas, 2010; Prestes et al., 2010). However, recently Fabré \& SaintPaul (1998) noted that flooded areas in tropical regions have sufficient seasonal change in water level to induce the appearance of growth checks in calcified structures in fishes. Many studies, therefore, have begun to analyze growth annuli in rigid structures of tropical fishes as a means of determining age and growth (Fabré \& SaintPaul, 1998; Pérez \& Fabré, 2003; Cutrim \& Batista, 2005; Holley et al., 2008).

Cichla is composed of fifteen species commonly known as "peacock bass" in English speaking countries, "tucunaré" in Brazil and "pavon" in Venezuela (Kullander \& Ferreira, 2006). Among these species, Cichla temensis is a highly sought after fish, due to its considerable size (up to $80 \mathrm{~cm}$ long and over $11 \mathrm{~kg}$ in weight); as a result, it is considered one of the most efficient predators of the genus (Winemiller et al., 1997). The size, speed, strength and ferocity of the peacock bass allow predation on almost all other fishes, making it an important species for sport fishing (Jepsen et al., 1997). The species is also very important for human consumption, particularly by riverine communities, and it is much valued in the ornamental fish trade (Soares et al., 2008). In spite of this, there is a dearth of studies of population parameters for this species, especially in natural environments (Jepsen et al., 1997; Winemiller et al., 1997; Jepsen et al., 1999).

In light of the above, this study sought to estimate the growth parameters - $\mathrm{L}_{\infty}$ (asymptotic length) and $\mathrm{k}$ (growth constant) - of C. temensis in the middle rio Negro in order to help determine the population structure and provide a scientific basis for the dynamics of this species to support management of $C$. temensis stocks in the middle rio Negro, Amazon sub-basin.

\section{Material and Methods}

Study area. The study was conducted in the middle rio Negro region $\left(00^{\circ} 58^{\prime} 00.5^{\prime \prime} \mathrm{S} 62^{\circ} 56^{\prime} 56.1^{\prime \prime} \mathrm{W}\right)$, close to the municipality of Barcelos in the state of Amazonas, Brazilian Amazonia (Fig. 1).

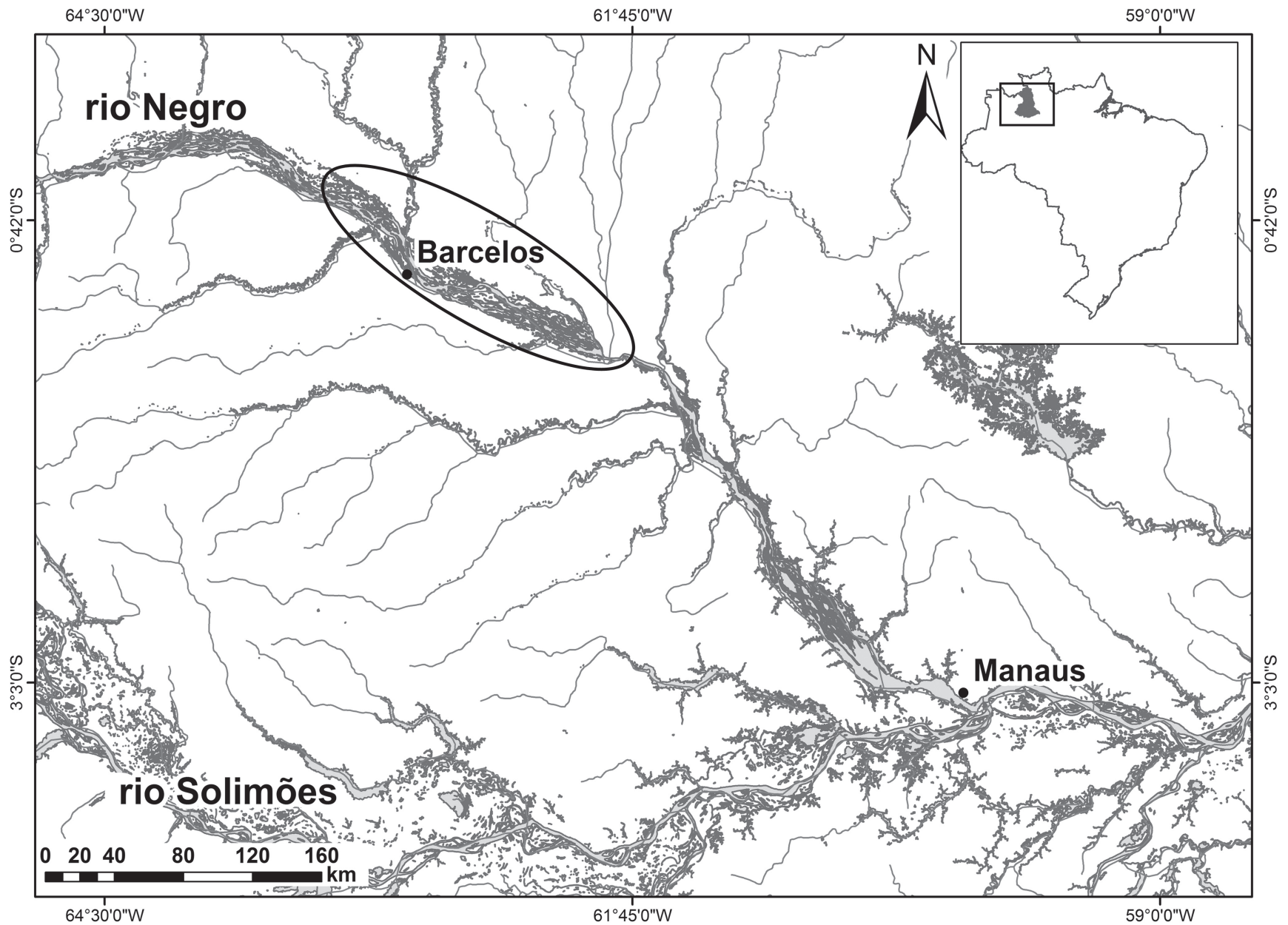

Fig. 1. Middle and lower stretch of the rio Negro (Amazonas, Brazilian Amazonia), with sampling area of Cichla temensis near the Barcelos municipality highlighted by a circle. 
Data sampling. Samples of Cichla temensis were obtained monthly between October 2011 and September 2012 in the main channel of the river, in the adjacent lakes and in the channels of the Mariuá archipelago. The specimens were obtained with rod-and-reel during four consecutive days of each month, fishing from 6:00 a.m. to 12:00 p.m. and 2:00 p.m. to 6:00 p.m. In order to find appropriate fishing areas and secure a reasonable number of samples and size classes, a professional guide was contracted to assist with collections. Fish were kept in coolers with ice and transported to Manaus, where the following biological data were collected: standard length $\left(\mathrm{L}_{\mathrm{s}}\right.$ in $\left.\mathrm{cm}\right)$ and total length $\left(\mathrm{L}_{\mathrm{t}}\right.$ in $\left.\mathrm{cm}\right)$, total weight $\left(\mathrm{W}_{\mathrm{t}}\right.$ in $\left.\mathrm{g}\right)$, body weight $\left(\mathrm{W}_{\mathrm{b}}\right.$ in $\mathrm{g}$ ), gonad weight ( $\mathrm{W}_{\mathrm{g}}$ in $\mathrm{g}$ ), sex and reproductive phases according to Brown-Peterson et al. (2011) adapted for this species (I: immature; II: developing; III: spawning capable and IV: regressing). A voucher specimen is deposited in the fish collection of the Instituto Nacional de Pesquisas da Amazônia (INPA 35563).

Scales to determine age and growth were sampled from the left flank of the fishes below the pectoral fin. Although approximately five scales were removed from each specimen using tweezers, only one scale with a welldefined nucleus was used to measure the growth rings. Upon removal, the scales were cleaned and maintained in envelopes with the same numbering as the fish. The selected scales were digitalized using a light-transmitted stereomicroscope.

Annuli were identified according to the criteria defined in Cordiviola (1974). Scales were examined in two independent readings at least one month apart by the same reader. Whenever the two readings disagreed, a third was taken. Only those scales with at least two concordant readings were considered for the analysis. Measurements (in $\mathrm{mm}$ ) were made of the distance from the central point of the scale (called focus) to the edge; and the distance from the focus to each ring, all at a $90^{\circ}$ angle. All measurements were made using AxioVision 2010 software, version 6.2. The correlation between standard length and scale length was also estimated.

The hydrological periods (dry, rising water, flood and receding water) were determined according to Bittencourt \& Amadio (2007) with adaptations for this work based on the data on water levels between October 2011 and September 2012 for the sampling area made available by the Brazilian Geological Service (CPRM) (Table 1).

Data analysis. The relative condition factor $(\mathrm{Kn})$ was calculated by the equation

$$
\mathrm{Kn}=\frac{W}{W e}
$$

proposed by Le Cren (1951), where $W$ is the total weight of an individual and We is the mean weight estimated for each length by the equation $W e=a * L s^{b}$, where $\mathrm{a}$ and $\mathrm{b}$ are the parameters from the weight-length relationship.
Table 1. Classification of hydrological periods according to the water level of the middle rio Negro.

\begin{tabular}{|c|c|c|c|}
\hline \multirow{2}{*}{$\begin{array}{l}\text { Hydrological } \\
\text { Period }\end{array}$} & \multirow{2}{*}{ Months } & Water Level & \multirow{2}{*}{ Criterion } \\
\hline & & $\begin{array}{l}\text { Mean } \pm \text { Standard } \\
\text { Deviation }(\mathrm{mm})\end{array}$ & \\
\hline \multirow{2}{*}{ Dry } & October/2011 & $351.16 \pm 9.93(\mathrm{n}=31)$ & \multirow{2}{*}{$\begin{array}{c}\text { Lowest water } \\
\text { level }\end{array}$} \\
\hline & November/2011 & $361.23 \pm 20.39(\mathrm{n}=30)$ & \\
\hline \multirow{5}{*}{ Rising Water } & December/2011 & $406.67 \pm 5.78(\mathrm{n}=31)$ & \multirow{5}{*}{$\begin{array}{c}\text { Rising water } \\
\text { level }\end{array}$} \\
\hline & January/2012 & $465.45 \pm 37.68(n=31)$ & \\
\hline & February/2012 & $565.13 \pm 43.56(n=29)$ & \\
\hline & $\operatorname{March} / 2012$ & $668.19 \pm 25.12(\mathrm{n}=31)$ & \\
\hline & April/2012 & $798.23 \pm 57.28(\mathrm{n}=30)$ & \\
\hline \multirow{2}{*}{ Flood } & May/2012 & $954.45 \pm 36.55(\mathrm{n}=31)$ & \multirow{2}{*}{$\begin{array}{c}\text { Highest } \\
\text { water level }\end{array}$} \\
\hline & June/2012 & $931.06 \pm 36.82(n=30)$ & \\
\hline \multirow{3}{*}{$\begin{array}{l}\text { Receding } \\
\text { Water }\end{array}$} & July/2012 & $843.54 \pm 13.65(n=31)$ & \multirow{3}{*}{$\begin{array}{l}\text { Receding } \\
\text { water level }\end{array}$} \\
\hline & August/2012 & $747.77 \pm 74.61(\mathrm{n}=31)$ & \\
\hline & September/2012 & $514.80 \pm 51.43(\mathrm{n}=30)$ & \\
\hline
\end{tabular}

Only females were used to determine the gonadosomatic index (GSI) because the variation in weight of ovaries is more noticeable than the variation for testicles. The index was calculated using the equation:

$$
\mathrm{GSI}=\frac{W g}{W t}
$$

where $W g=\operatorname{gonad}$ weight $(g)$ and $W t=$ total weight $(g)$.

Annuli were validated by marginal relative increment (MRI) analysis:

$$
\mathrm{MRI}=\frac{R-R_{n}}{R_{n}-R_{n-1}} *(100)
$$

where $\mathrm{R}=$ total radius (measured from the focus to the edge of the scale); $R_{n}=$ annulus radius measured from the focus to the last annulus of the scale; and $R_{n-1}=$ annulus radius measured from the focus to the penultimate annulus of the scale. To determine the period when annuli were formed, the frequency distribution of the MRI grouped into intervals of 20 units of MRI was used. Annulus formation was considered to occur in the period when there was a decrease in mean MRI values followed by an increase.

The homogeneity of GSI, Kn and MRI was verified with the Bartlett test, using Statistica 9.0 software (StatSoft, 2009). Since the data did not pass the homogeneity test, the Kruskal Wallis test was applied at a 0.05 significance level to verify if there were differences in the GSI, Kn and MRI averages among hydrological periods. A posteriori tests were performed whenever significant differences were found.

Individual age was calculated by counting the number of annuli in each specimen's scales. The mean standard length of specimens with the same number of annuli was also calculated. 
The model proposed by von Bertalanffy (1938),

$$
L_{t}=L_{\infty}\left[1-e^{-k(t-t)}\right]
$$

was used to represent the species' growth curve, where $\mathrm{L}_{\mathrm{t}}=$ length of individuals at age $\mathrm{t}, \mathrm{L}_{\infty}=$ asymptotic length, $\mathrm{k}=$ growth constant, $\mathrm{t}=$ age and $\mathrm{t}_{0}=$ theoretical age when length is zero. The parameter $t_{0}$ was considered zero because an individual's initial size is negligible and, furthermore, this parameter does not have a biological connotation. The growth parameters $\mathrm{L}_{\infty}$ and $\mathrm{k}$ in von Bertalanffy's equation were determined by adjusting them to the age and standard length data by non-linear adjustment of the variables using the SIMPLEX iterative method in the Statistica package (StatSoft, 2009).

Longevity $\left(\mathrm{A}_{0.95}\right)$, defined as the time that an individual takes to reach $95 \%$ of its maximum length, was estimated based on the formula proposed by Taylor (1958):

$$
\mathrm{A}_{0,95}=\frac{t_{0}+2,996}{k}
$$

where $\mathrm{A}_{0.95}=$ longevity, $t_{0}=$ theoretical age at length zero and $k=$ growth constant in von Bertalanffy's equation.

Length at first sexual maturity $\left(\mathrm{L}_{50}\right)$ was estimated by calculating the percentage of adult females (maturity stages II, III and IV) by length intervals of $1 \mathrm{~cm}$. Data were adjusted using the logistic function proposed by King (1995):

$$
y=\frac{1}{\left(1+e^{-b 1^{*}(x-b 2)}\right)}
$$

where $y=$ length, $x=$ no. of female adults, $b 1=\mathrm{L}_{50}$ and $b 2=$ standard deviation.

\section{Results}

Between October 2011 and September 2012, a total of 250 Cichla temensis specimens were collected. Standard length varied between 21.5 and $53.5 \mathrm{~cm}$ (mean 33.30 $\pm 5.34 \mathrm{~cm})$.

Up to six growth annuli were identified on the scales, however, only the second annulus onwards could be verified as true growth rings. The frequency distributions of the mean distances between the center of the scale and each mark identified were unimodal, indicating that the annuli could be consistently identified. The progressive dislocation of the modal values to the right as the number of annuli increased also indicates consistency in the identification of the annuli (Fig. 2).

The coefficient of determination between standard length and scale length (total radius) was $70 \%$, indicating proportionality between the size of the fish and the structure (scale) used to determine the age of the species (Fig. 3).
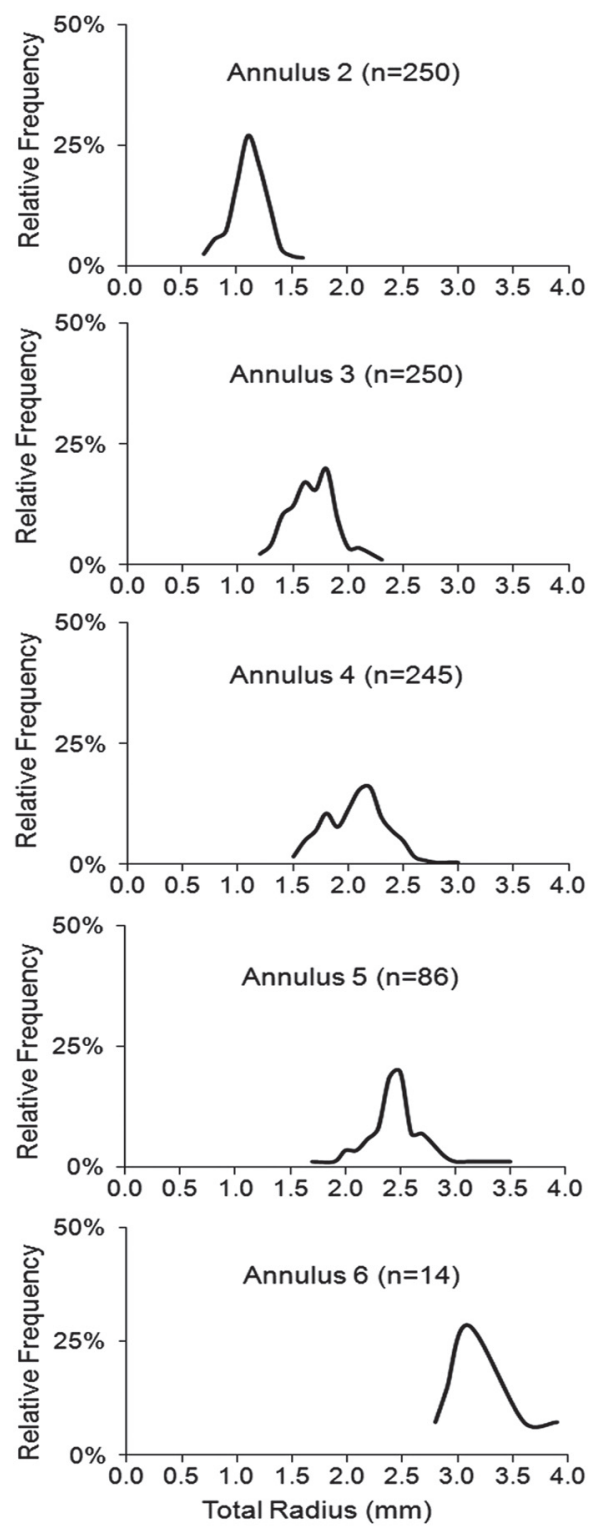

Fig. 2. Frequency distribution of distances between the focus and each annulus identified on the scales of Cichla temensis from the middle rio Negro.

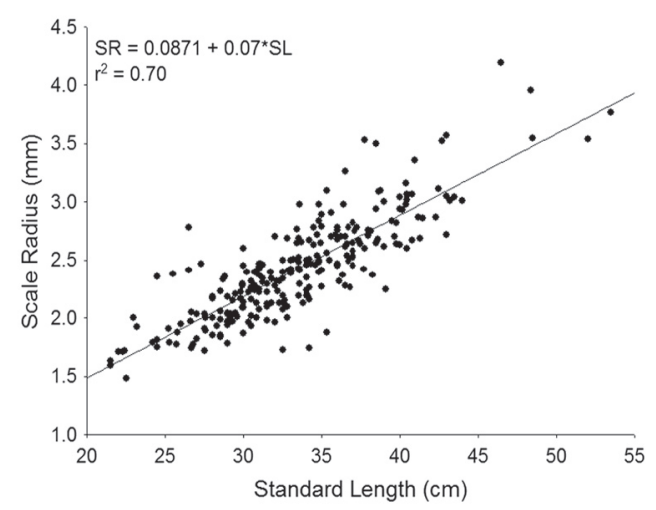

Fig. 3. Relationship between standard length $(\mathrm{cm})$ and total scale radius $(\mathrm{mm})$ of Cichla temensis from the middle rio Negro. $\mathrm{SL}=$ standard length; $\mathrm{SR}=$ scale radius. 
There were no significant differences in the mean values of condition $(\mathrm{Kn})$ over the period studied $\left(\chi_{3,246}^{2}\right.$ $=6.80 ; p>0.05)$ (Fig. 4a), and the GSI was significantly higher during the receding-water period $\left(\chi^{2}=8.68 ; \mathrm{p}=\right.$ 0.03 ), indicating that $C$. temensis reproduce mainly during this period (Fig. 4b).
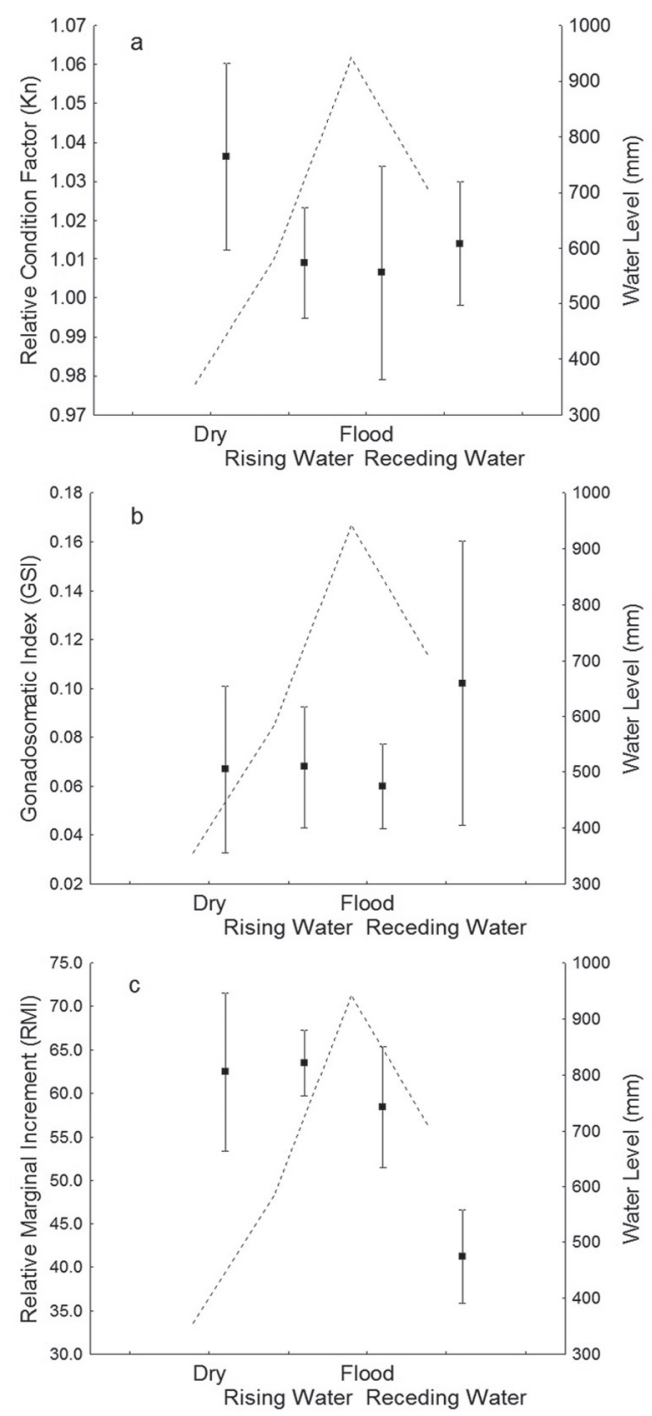

Fig. 4. Variation in the condition factor (a), gonadosomatic index (b), and marginal relative increment (c) of Cichla temensis according to hydrological period and the water level of the middle rio Negro between October 2011 and September 2012.

Similarly, the mean value of MRI was significantly lower during the receding-water period $\left(\chi^{2}=21.05 ; p=0.01\right)$, indicating that annuli were formed during this hydrological period (Fig. 4c). When the MRI frequency distributions for the different hydrological periods were analyzed, a modal class progression to the left was observed (Fig. 5). During the receding-water period the majority of the specimens showed a smaller growth increment $(20 \%)$, corroborating the results of MRI, where a significant decrease in values for this period was observed. During the dry season the majority of individuals had an MRI of $80 \%$, indicating that an increment in body growth occurred between the receding-water and dry periods (Fig. 5). Annulus formation for $C$. temensis was therefore considered to occur once a year during the receding-water period.
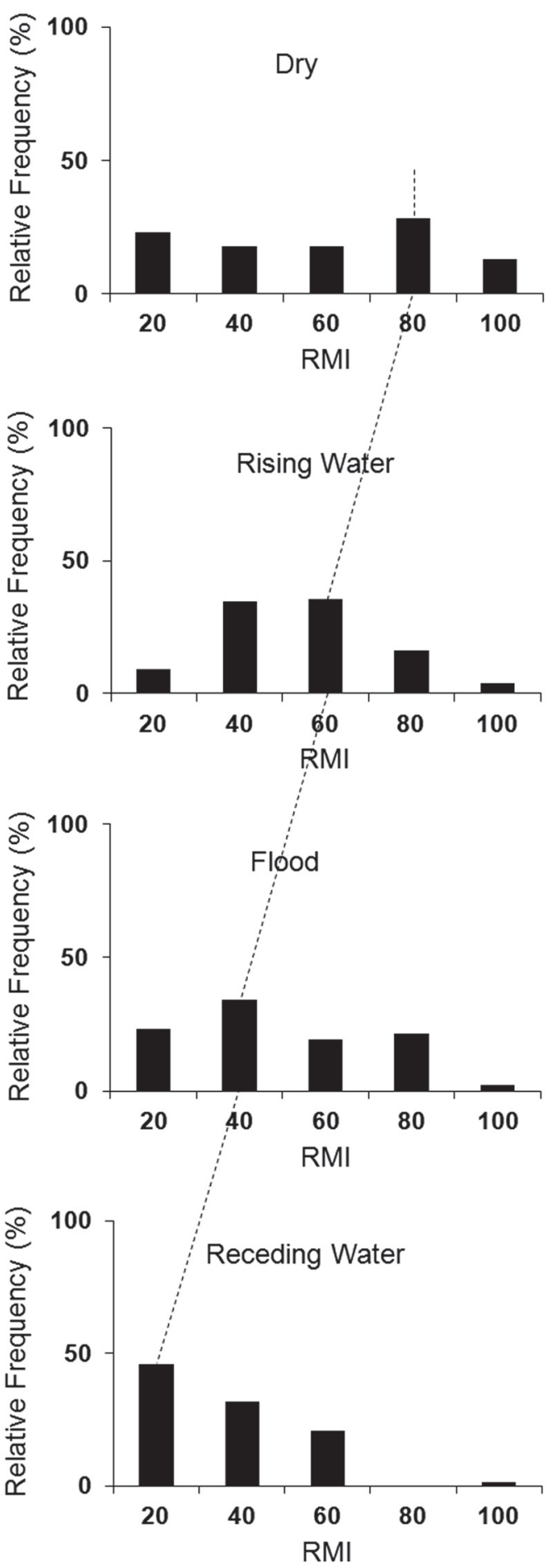

Fig. 5. Relative frequency distribution of RMI observed on scales of Cichla temensis from the middle rio Negro for each hydrological period. 
Size at first sexual maturity was estimated as $\mathrm{L}_{50}=31.11$ $\mathrm{cm}$ of standard length. Assuming that one annulus is formed per year, as indicated by the MRI analysis, intervals of one year were attributed to each annulus. The minimum and maximum number of annuli identified was two and six, respectively, and $90 \%$ of the specimens had three or four annuli. The mean standard length and number of fishes for each number of annuli (two to six) are shown in Table 2.

Table 2. Number of annuli, mean standard length and number of Cichla temensis specimens.

\begin{tabular}{ccc}
\hline \multirow{2}{*}{ Number of annuli } & \begin{tabular}{c} 
Standard Length $(\mathrm{cm})$ \\
\cline { 2 - 2 }
\end{tabular} & $\begin{array}{c}\text { Mean } \pm \text { Standard } \\
\text { Deviation }(\mathrm{cm})\end{array}$ \\
\hline 2 & $22.03 \pm 0.44$ & 6 \\
3 & $31.10 \pm 3.18$ & 158 \\
4 & $37.32 \pm 3.27$ & 72 \\
5 & $42.87 \pm 2.84$ & 11 \\
6 & $51.33 \pm 2.56$ & 3 \\
\hline
\end{tabular}

Adjustment of standard lengths for age using von Bertalanffy's growth model provided the growth parameters $\mathrm{L} \infty=68.05 \mathrm{~cm}, \mathrm{k}=0.20 \mathrm{yr}^{-1}$ and $\mathrm{A}_{0.95}=14 \mathrm{yr}$ and the corresponding growth curve (Fig. 6).

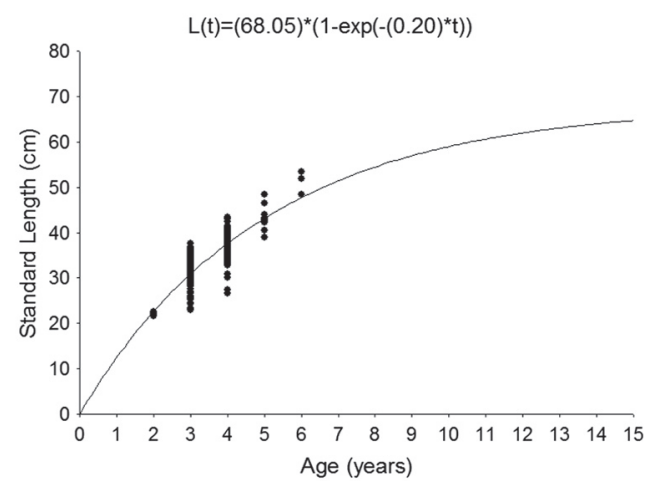

Fig. 6. Length growth curve for Cichla temensis from the middle rio Negro.

\section{Discussion}

Estimates of age and growth rate in tropical fish using growth rings registered on otoliths and scales have been increasing steadily in recent years (Fabré \& Saint-Paul, 1998; Jepsen et al., 1999; Pérez \& Fabré, 2003; Cutrim \& Batista, 2005; Holley et al., 2008). For Cichla temensis, the establishment of growth rings is principally linked to the reproductive period and parental care of fry (Jepsen et al., 1999; Montaña et al., 2006; Holley et al., 2008). The number of visible annuli (up to six) on the scales of $C$. temensis was similar to that reported by Winemiller et al. (1997) (seven to nine), Jepsen et al. (1999) (eight) and Holley et al. (2008) (nine). The differences in the results may be because: i) we used scales for the readings while the other authors used otoliths; and ii) the fish specimens analyzed were larger than in this study and therefore had more annuli. However, it is important to note that all of the cited studies followed the premise of proportionality between the size of the specimen and size of the otolith/ scale (Fonteles Filho, 2011).

The annual variation in relative body condition $(\mathrm{Kn})$ observed for Cichla temensis suggests that this species obtains and stores energy mainly during the dry season, when the water level recedes and fish density in aquatic habitats increase, enabling the detection and capture of prey by this piscivorous fish (Jepsen et al., 1997; Winemiller et al., 1997; Rabelo \& Araújo-Lima, 2002; Montaña et al., 2006), culminating in higher growth during this period. The results for the GSI indicated that most of the reproductive activity of $C$. temensis occurred during the receding-water period. During the spawning period, fishes may have an energy deficit because of reproductive activities, nest construction and parental care (Braga, 1952; Zaret, 1980; Jepsen et al., 1999; Montaña et al., 2006; Holley et al., 2008). Thus, the process of energy allocation for these activities would explain the decrease in growth rate and consequent formation of an annulus on the scales of $C$. temensis during the receding-water period and spawning peak, as confirmed by the MRI analysis. This corroborated with the results of Jepsen et al. (1999) and Holley et al. (2008), who also studied growth parameters of $C$. temensis in rivers and dams in Venezuela and the middle rio Negro, respectively. Both studies confirmed that annuli were formed during the reproductive period, which also coincided with a reduction in feeding.

In this study, the first ring, which refers to the first year of life, could not be identified due to difficulties in being able to accurately visualize it. The second ring corresponded to specimens with an average standard length of 22.03 $\mathrm{cm}$. Instead of reproductive activity being the prime influence, we believe that formation of the second ring could be related to environmental conditions and/or biotic interactions, such as competition and territorialism (King, 1995). The average size at first sexual maturation $\left(\mathrm{L}_{50}\right)$ for this species was calculated at $31.1 \mathrm{~cm}$, which coincided with the average standard length determined for formation of the third annulus. These findings corroborated with the results of Winemiller et al. (1997) and Montaña et al. (2007), who found similar $\mathrm{L}_{50}$ values of $36 \mathrm{~cm}$ and $32.6 \mathrm{~cm}$, respectively. Therefore, it appears that individuals with two annuli are juvenile fish $(<31.1 \mathrm{~cm})$, while those with three or more rings are adults $(\geq 31.1 \mathrm{~cm})$, with the first sexual maturation occurring at approximately three years, assuming the formation of one ring per year.

The lack of large tucunaré specimens sampled in the present study likely explains the difference between the estimated longevity of this species in the study area (14 years) and the age associated with the number of growth rings measured on the scales (6 years). The difficulty in finding large specimens was probably due to the constant 
presence of sport fishermen during the low water season, which is the best time for catching tucunaré, and the fact that this fishing pressure then drives the bigger fish to remote headwater areas of rio Negro tributaries located far way from our sampling area. Asymptotic length $\left(\mathrm{L}_{\infty}\right)$ is affected by factors such as the availability of food and population density, while growth rate (k) is genetically and/or physiologically determined and influenced by environmental factors (Beverton \& Holt, 1957; Pauly, 1980). The premise described by Beverton \& Holt (1957) and Ricker (1975), that an inverse relationship exists between growth rate $(\mathrm{k})$ and asymptotic length $\left(\mathrm{L}_{\infty}\right)$, i.e, whereby the greater the growth rate, the lower the asymptotic length and longevity, can be confirmed by studies conducted in the Amazon region (Table 3). This relationship is also applicable to Cichla temensis, which has been corroborated in the studies of Jepsen et al. (1999) and Holley et al. (2008) (Table 3). However, the k values for Cichla monoculus (Campos \& Freitas, 2010), C. intermedia and C. orinocensis (Jepsen et al., 1999) were higher and the $\mathrm{L}_{\infty}$ values lower than those found for $C$. temensis in the present study. While studying the growth, biological characteristics and ecology of $C$. temensis, Winemiller et al. (1997), Jepsen et al. (1999) and Montaña et al. (2006) confirmed that this species reaches sizes significantly greater than other species from the same genus. Hence, according to Winemiller's (1989) classification, C. temensis can be defined as a species in equilibrium because of its sedentary characteristics, its long life cycle and the fact that it is medium-sized.

Table 3. Estimated growth coefficients and asymptotic lengths for Amazon fish species showing the inverse relationship between $\mathrm{k}$ and $\mathrm{L} \infty$.

\begin{tabular}{|c|c|c|c|}
\hline Reference & Species & $\mathrm{k}\left(\right.$ year $\left.^{-1}\right)$ & $\mathrm{L}_{\infty}(\mathrm{cm})$ \\
\hline \multirow{3}{*}{ Prestes et al. (2010) } & Triportheus albus & 0.86 & 24.68 \\
\hline & Triportheus angulatus & 0.77 & 26.78 \\
\hline & Triportheus auritus & 0.65 & 27.83 \\
\hline Bevilaqua \& Soares (2010) & Pygocentrus nattereri & 0.63 & 29.4 \\
\hline Santos-Filho \& Batista (2009) & Brycon amazonicus & 0.57 & 51.00 \\
\hline Cutrim \& Batista (2005) & Hypophthalmus marginatus & 0.55 & 52.63 \\
\hline \multirow{2}{*}{ Campos \& Freitas (2010) } & \multirow{2}{*}{ Cichla monoculus } & 0.38 & 53.55 \\
\hline & & 0.25 & 59.91 \\
\hline Present Study (2014) & \multirow{3}{*}{ Cichla temensis } & 0.20 & 68.05 \\
\hline Holley et al. (2008) & & 0.18 & 83.00 \\
\hline Jepsen et al. (1999) & & 0.16 & 84.37 \\
\hline
\end{tabular}

In conclusion, the use of scales to determine growth parameters in Cichla temensis proves an effective and reliable technique to study the influence of the hydrological cycle on growth patterns. Furthermore, this technique provides insights into population dynamics of the species, which can help to develop models aimed at estimating the effects of fishing pressure on exploited stocks. Considering that $C$. temensis is the principal species in the thriving sport fishery of the middle rio Negro, conservation programs are essential to ensure that fish populations remain steady and sustainable over the long term.

\section{Acknowledgments}

The authors would like to thank the Fundação de Amparo à Pesquisa do Estado do Amazonas (FAPEAM) and the Conselho Nacional de Desenvolvimento Científico e Tecnológico (CNPq) for providing financial support for this study, guide Admo Carneiro for help with field work, and the Universidade Federal de Rondônia for allowing us to use the equipment in the Ichthyology Laboratory.

\section{References}

von Bertalanffy, L. 1938. A quantitative theory of organic growth (inquiries on growth laws II). Human Biology, 10: 181-213.

Beverton, R. J. H. \& S. J. Holt. 1957. On the dynamics of exploited fish populations. London, Her Majesty's stationery Office, 533p. (Fishery investigation series II, v. 19).

Bevilaqua, D. R. \& M. G. M. Soares. 2010. Crescimento e mortalidade de Pygocentrus nattereri Kner, 1985 em lagos de várzea da região de Manacapuru, Amazônia. Revista Brasileira de Engenharia de Pesca, 5: 43-52.

Bittencourt, M. M. \& S. A. Amadio. 2007. Proposta para identificação rápida dos períodos hidrológicos em áreas de várzea do rio Solimões-Amazonas nas proximidades de Manaus. Acta Amazonica, 37: 303-308.

Braga, R. A. 1952. Ninhos de tucunarés "Cichla temensis" Humboldt e "Cichla ocellaris" Bloch \& Schneider (Actinopterygii, Cichlidae). Revista Brasileira de Biologia, 12: $273-278$.

Brown-Peterson, N. J., D. M. Wyanski, F. Saborido-Rey, B. J. Macewicz \& S. K. Lowerre-Barbieri. 2011. A Standardized terminology for describing reproductive development in fishes. Marine and Coastal Fisheries: Dynamics, Management, and Ecosystem Science, 3: 52-70.

Campos, C. P. \& C. E. C. Freitas. 2010. Curva de crescimento do tucunaré Cichla monoculus Spix \& Agassiz, 1831 do Lago Grande de Manacapuru, Amazonas, Brasil. Revista Brasileira de Engenharia de Pesca, 5: 1-9.

Casselman, J. M. 1983. Age and growth assessment of fish from their calcified structures-techniques and tools. NOAA Technical Report NMFS, 8: 1-17.

Cordiviola de Yuan, E. L. L. 1974. La edad en los peces: su determinacion en species del Paraná Médio. Revista de la Asociacion de ciencias Naturales del Litoral, 5: 53-69.

Cutrim, L. \& V. S. Batista. 2005. Determinação de idade e crescimento do mapará (Hypophthalmus marginatus) na Amazônia Central. Acta Amazônica, 35: 85-92.

Fabré, N. N. \& U. Saint-Paul. 1998. Annulus formation on scales and seazonal growth of the Central Amazonian Anostomid Schizodon fasciatus. Journal of Fish Biology, 53: 1-11.

Fonteles Filho, A. A. 2011. Oceanografia, biologia e dinâmica populacional de recursos pesqueiros. Fortaleza, Editora da Universidade Federal do Ceará, 464p. 
Holley, M. H., M. J. Maceina, M. Thomé-Souza \& B. R. Forsberg. 2008. Analysis of the trophy sport fishery for the speckled peacock bass in the Rio Negro River, Brazil. Fisheries Management and Ecology, 15: 93-98.

Isaac, V. J. \& M. L. Ruffino. 1996. Population dynamics of tambaqui, Colossoma macropomum Cuvier, in the Lower Amazon, Brazil. Fisheries Management and Ecology, 3: 315-333.

Jepsen, D. B., K. O. Winemiller, D. C. Taphorn \& D. Rodrigues Olarte. 1997. Temporal patterns of resource partitioning among Cichla species in a Venezuelan blackwater river. Journal of Fish Biology, 51: 1085-1108.

Jepsen, D. B., K. O. Winemiller \& D. C. Taphorn. 1999. Age structure and growth of peacock cichlids from rivers and reservoirs of Venezuela. Journal of Fish Biology, 55: 433-450.

King, M. 1995. Fisheries biology, Assessment and management. Fishing New Books. Oxford, England, 341p.

Kullander, S. O. \& E. J. G. Ferreira. 2006. A review of the South American cichlid genus Cichla, with descriptions of nine new species (Teleostei: Cichlidae). Ichthyological Exploration of Freshwaters, 17: 289-398.

Le Cren, E. D. 1951. The length-weight relationship amd seasonal cycle in gonad weight and condition in the perch (Perca fluviatilis). Journal of Animal Ecology, 20: 201-219.

Montaña, C., D. Taphorn, C. Layman \& C. A. Lasso. 2006. Distribución, alimentación y reproducción de tres especies de pavones Cichla spp.(Perciformes, Cichlidae) en la cuenca baja del río Ventuari, Estado Amazonas, Venezuela. Memoria de la Fundación La Salle de Ciencias Naturales, 165: 83-102.

Pauly, D. 1980. On the interrelationships between natural mortality, growth parameters, and mean environmental temperature in 175 fish stocks. Ices Journal of Marine Science, , 39: 175-192.

Pérez, A. \& N. N. Fabré. 2003. Seleção das estruturas calcificadas para a determinação da idade da Piracatinga Calophysus macropterus Lichtenstein (Siluriformes: Pimelodidae) na Amazônia Central, Brasil. Acta Amazonica, 33: 499-514.

Petrere Jr., M. 1983. Yield per recruit of the Tambaqui, Colossoma macropomum Cuvier, in the Amazonas state, Brazil. Journal of Fish Biology, 22: 133-144.

Prestes, L., M. G. M. Soares, F. R. Silva \& M. M. Bittencourt. 2010. Dinâmica populacional de Triportheus albus, T. angulatus e T. auritus (CHARACIFORMES: CHARACIDAE) em lagos da Amazônia Central. Biota Neotropical, 10: 177-181.
Rabelo, H. \& C. A. R. M. Araújo-Lima. 2002. A dieta e o consumo diário de alimento de Cichla monoculus na Amazônia Central. Acta Amazonica, 32: 707-724.

Ricker, W. E. 1975. Computation and interpretation of biological statistics of fish populations. Bulletin Fisheries Resources Board Canadian, 191: 1-382.

Ruffino, M. L. \& V. J. Isaac. 1999. Dinâmica populacional do surubim-tigre, Pseudoplatystoma tigrinum (Valenciennes, 1840) no Médio Amazonas (Siluriformes, Pimelodidae ). Acta Amazonica, 29: 463-476.

Santos Filho, L. C. \& V. S. Batista. 2009. Dinâmica populacional da matrinxã Brycon amazonicus (Characidae) na Amazônia Central. Zoologia, 26: 195-203.

Soares, M. G. M., E. L. Costa, F. K. Siqueira-Souza, H. D. B. Anjos, K. C. Yamamoto \& C. E. C. Freitas (Orgs.). 2008. Peixes de lagos do Médio rio Solimões. Manaus, Edua, $176 \mathrm{p}$.

StatSoft, Inc 2009. STATISTICA (data analysis software systems), version 9.0. www.statsoft.com.

Taylor, C. C. 1958. Cod growth and temperature. Journal Du Conseil, 23: 366-370.

Weatherley, A. H. 1972. Growth and ecology of fish populations. London, Academic Press, 293p.

Weatherley, A. H. \& H. S. Gill. 1987. The biology of fish growth. London, Academic Press, p. 1-21.

Welcomme, R. L. 1992. Pesca fluvial. Roma, FAO, 303p. (FAO Documento Técnico de Pesca 262).

Winemiller, K. O. 1989. Patterns of variation in life history among South American fishes in seasonal environments. Oecologia, 81: 225-241.

Winemiller, K. O., D. C. Taphorn \& A. Barbarino-Duque. 1997. Ecology of Cichla (Cichlidae) in two blackwater rivers of Southern Venezuela. Copeia, 4: 690-696.

Zaret, T. M. 1980. Life history and growth relationships of Cichla ocellaris, a predatory South American ciclid. Biotropica, 12: 144-157.
Submitted June 17, 2014 Accepted January 21, 2015 by Fernando Pelicice Published June 30, 2015 